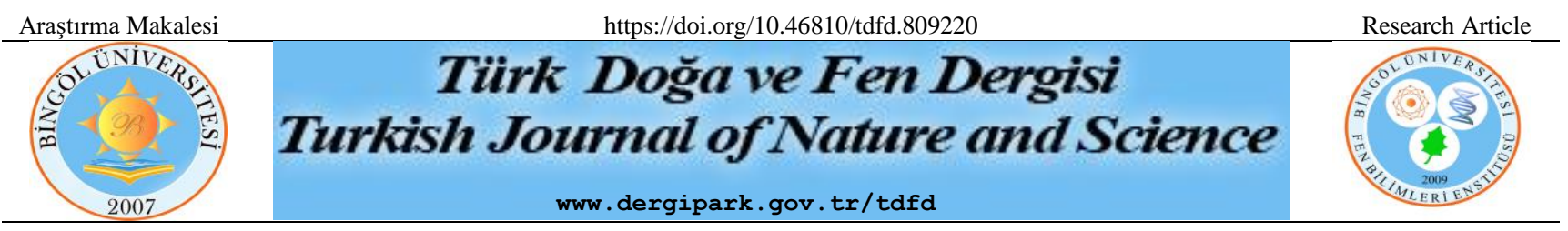

\title{
Bortezomib ile Kalp Hasarı Olușturulan Ratlarda Berberinin Oksidatif ve Nitrozatif Stres Üzerine Etkisi
}

\author{
Cihan GÜR ${ }^{1 *}$, Fatih Mehmet KANDEMİ ${ }^{1}$, Aydın GENÇ ${ }^{1}$ \\ ${ }^{1}$ Atatürk Üniversitesi, Veteriner Fakültesi, Biyokimya Anabilim Dalı, Erzurum, Türkiye \\ Cihan GÜR ORCID No: 0000-0001-6775-7858 \\ Fatih Mehmet KANDEMIR ORCID No: 0000-0002-8490-2479 \\ Aydın GENÇ ORCID No: 0000-0001-5367-0743 \\ *Sorumlu yazar: cihan.gur@atauni.edu.tr
}

(Alınış: 12.10.2020, Kabul: 14.12.2020, Online Yayınlanma: 30.12.2020)

\begin{abstract}
Anahtar
Kelimeler

Berberin,

Bortezomib,

Kalp,

Nitrozatif

Stres,

Oksidatif

Stres,

Rat

Öz: Bortezomib (BTZ), proteazom sistemini bloke ederek hücresel protein yıkımını engelleyen yeni nesil bir antineoplastik ilaçtır. Bu çalışmada BTZ kaynaklı kalp hasarına karşı bir izokinolin alkaloid olan berberinin (BBR) koruyucu etkileri araştırılmıştır. Çalışmada erkek Sprague Dawley cinsi ratlara 1., 3., 5. ve 7. günlerde periton içi $0,2 \mathrm{mg} \mathrm{kg}^{-1} \mathrm{BTZ}$ ve 10 gün boyunca her gün 50 ve $100 \mathrm{mg} \mathrm{kg}^{-1}$ dozlarda BBR verildi. Ratların kalp dokularında malondialdehit (MDA), glutatyon (GSH), total antioksidan kapasite (TAK), total oksidan kapasite (TOK) ve nitrik oksit (NO) seviyeleri ile süperoksit dismutaz (SOD), katalaz (KAT), glutatyon peroksidaz (GPx) ve laktat dehidrogenaz (LDH) aktiviteleri biyokimyasal yöntemler ile analiz edildi. Veriler BTZ'nin kalp dokusunda MDA, NO ve TOK seviyelerini, serumda LDH aktivelerini ve oksidatif stres indeksini (OSI) önemli ölçüde arttırdığını, GSH ve TAK seviyeleri ile SOD, KAT ve GPx aktivitelerini azaltarak oksidatif stresi tetiklediğini buna bağlı olarak dokuda hasar oluşturduğunu gösterdi. Buna karşın BBR, BTZ'nin neden olduğu oksidatif stresi ve nitrozatif stresi hafifleterek kalp hasarına karşı koruyucu etki gösterdi. Sonuçlara göre BBR'nin, BTZ ile indüklenen kardiyak toksisiteye karşı daha ileri çalışmalardan sonra koruyucu olarak kullanılabileceğini gösterdi.
\end{abstract}

\section{The Effect of Berberine on Oxidative and Nitrosative Stress in Rats with Bortezomib-Induced Heart Damage}

Keywords
Berberine,
Bortezomib,
Heart,
Nitrosative
Stres,
Oxidative
Stres,
Rat

\section{Keywords}

Bortezomib

Heart,

Nitrosative

Oxidative

Rat

\begin{abstract}
Bortezomib (BTZ) is a new generation antineoplastic drug that blocks cellular protein degradation by blocking the proteasome system. In this study, the protective effects of berberine (BBR), an isoquinoline alkaloid, against BTZ-induced heart damage were investigated. In the study, male Sprague Dawley rats were given intraperitoneal $0.2 \mathrm{mg} \mathrm{kg}^{-1} \mathrm{BTZ}$ on the $1 \mathrm{st}$, 3rd, 5th and 7th days and BBR doses of 50 and $100 \mathrm{mg} \mathrm{kg}^{-1}$ every day for 10 days. In the heart tissues of rats, malondialdehyde (MDA), glutathione (GSH), total antioxidant capacity (TAC), total oxidant capacity (TOC) and nitric oxide (NO) levels and superoxide dismutase (SOD), catalase (CAT), glutathione peroxidase $(\mathrm{GPx})$ and lactate dehydrogenase (LDH) activities were analyzed by biochemical methods. The data showed that BTZ significantly increased MDA, NO and TOC levels in heart tissue, LDH activities in serum and oxidative stress index (OSI), triggered oxidative stress by decreasing GSH and TAC levels and SOD, CAT and GPx activities, thereby causing tissue damage. On the other hand, BBR showed a protective effect against heart damage by relieving oxidative stress and nitrosative stress caused by BTZ. The results showed that the BBR can be used as a protective agent against BTZ-induced cardiac toxicity after further studies.
\end{abstract}




\section{GİRIŞ}

Ubikuitin proteazom sistemi (UPS), hücre içi protein yıkımını düzenlemek için temel hücresel yoldur. $\mathrm{Bu}$ yol birkaç bileşenden oluşan karmaşık bir proteolitik mekanizma ile gerçekleştirilir. Araştırmacılar 1980'lerin başında UPS'in özelliklerinin belirlenmesinden kısa bir süre sonra, yeni proteazom inhibitörlerinin geliştirilmesiyle birlikte tümör hücrelerinde seçici olarak apoptozu indüklemek için birkaç girișimde bulunmuşlardır $[1,2]$.

Boronik asit dipeptidi olan bortezomib (BTZ), proteazom sistemini bloke ederek hücresel protein yıkımını engelleyen yeni nesil bir antineoplastik ilaçtır. ABD Gıda ve İlaç Dairesi (FDA) tarafından 2003 yılında başta multipl miyelom olmak üzere prostat, meme, akciğer, böbrek ve yumurtalık kanserleri gibi çeşitli tümörlerin tedavisinde kullanılmak üzere onay verilmiş ve yaygın bir şekilde kullanıma başlamıştır [3, 4]. BTZ, ubikuitin-proteazom sistemi yoluyla hücre içi proteinlerin parçalanmasından sorumlu olan $26 \mathrm{~S}$ proteazomunun proteaz aktivitesini inhibe etmektedir. Proteazomal aktivitenin inhibisyonu, çoklu hücre sinyalizasyonunu ve diğer yolakları bozmakta, hücre döngüsünün bozulmasına yol açmakta ve apoptozu ve aktif hücre ölümünü indüklemektedir [5]. BTZ'nin, maya $20 \mathrm{~S}$ proteazomunun $\beta 5$ alt biriminde treonin1 (Thr1) ile son derece güçlü, ancak tersine çevrilebilir bir kompleks oluşturduğu gösterilmiştir [6]. BTZ'nin bu etkileri kötü huylu hücrelerde daha şiddetli olsa da normal hücrelerin de bu durumdan etkilenmesi kaçınılmazdır [3]. Tersinir bir proteazom inhibitörü olan BTZ ile tedavinin yan etkileri esas olarak nörolojik komplikasyonlarla (periferal nöropati) ilişkilidir [7]. Bununla birlikte son vaka raporları, BTZ ile tedavinin kardiyak olaylarla ilişskili olabileceğine dair endişe verici kanıtlar sunmaktadır $[8,9]$.

Fitokimyasallar, koruyucu veya hastalık önleyici etkilere sahip olan fakat besleyici özellikleri bulunmayan bitkisel kimyasallardır [10]. Maliyetlerinin düşük olması ve doğal gıdalardan kolayca elde edilmelerinden dolayı bu kimyasallara olan ilgi her geçen gün artmaktadır [11]. Klinik öncesi çalışmalar, fitokimyasallara ait antioksidan, anti-enflamatuvar ve anti-apoptotik özellikleri de dahil olmak üzere kardiyoprotektif etkilerinin altında yatan çeşitli mekanizmaları tanımlamışlardır [12]. Başta Hydrastis canadensis L. olmak üzere Berberidaceae ve Ranunculaceae familyalarına ait birçok bitkiden izole edilen bir alkaloid olan berberin (BBR) (5,6-dihidro-9,10dimethoksibenzo[g]-1,3-benzodioksolo [5,6- $\alpha]$ kinolizinyum), geleneksel Çin tıbbında uzun yıllardan beri kullanılmaktadır [13]. Bu bileşik, antioksidan, antienflamatuar, anti-mikrobiyal, anti-kanser, antihipertansif, renoprotektif ve anti-hiperglisemik gibi geniş bir biyolojik aktiviteye sahiptir [14, 15]. BBR, reaktif oksijen türleri (ROS) ve reaktif nitrojen türleri (RNS) için bir tutucu olarak hareket ederek serbest radikallere karşı koruyucu bir etkiye sahiptir. Ayrıca BBR'nin süperoksit dismutaz (SOD), katalaz (KAT) ve glutatyon peroksidaz (GPx) gibi antioksidan enzimleri aktive ettiği bilinmektedir. BBR'nin malondialdehit (MDA) ve nitrik oksit (NO) gibi oksidatif stres parametrelerinin seviyelerini ise azalttığı gösterilmiştir [15]. Literatürde BBR'nin kardiyovasküler sistem üzerine bir dizi yararlı etkisinin olduğu bildirilmesine rağmen bu etkilerin mekanizması hala net olarak aydınlatılamamıştır [13].

Sunulan çalışmada BTZ ile kalp hasarı oluşturulan ratlarda, BBR'nin etkilerinin bazı biyokimyasal parametreler ile araştırılması amaçlanmıștır.

\section{MATERYAL VE METOT}

\subsection{Kimyasallar}

Bortezomib (3,5 $\mathrm{mg}$ IV/SC), Koçak Farma'dan (İstanbul, Türkiye) temin edildi. Berberin ve diğer kimyasallar Sigma-Aldrich'ten (St. Louis, MO, ABD) satın alınd1.

\subsection{Deneyde Kullanılan Hayvanlar}

Çalışmanın yürütülebilmesi için gerekli olan etik kurul onay1, Atatürk Üniversitesi Hayvan Deneyleri Yerel Etik Kurulu'ndan alınmıştır (Onay no: 2020-9/133). Deneyde yaşları 8-10 haftalık olan toplam 35 adet Sprague Dawley cinsi erkek rat kullanılmıştır. Deney başlangıcında hayvanların ağırlıkları 250-270 g'dı. Atatürk Üniversitesi Tibbi Deneysel Uygulama ve Araştırma Merkezi'nden (Erzurum, Türkiye) temin edilen ratların deneysel uygulamaları yine bu merkezde gerçekleştirilmiştir. Uygulama öncesi 1 haftalık süre boyunca ratların ortama adaptasyonları sağlandı. Ortam şartları $24 \pm 1{ }^{\circ} \mathrm{C}$ ve $45 \pm 5 \%$ nem oranına sahipti. Ayrıca ratların bulundukları ortamın 12 saat aydınlık/karanlık döngüsüne sahip olması sağlandı. Ratlar ad libitum olarak verilen standart pelet yem ve musluk suyu ile beslendiler.

\section{3. Çalışma Dizaynı}

Ratlar her grupta 7 adet olacak şekilde 5 gruba ayrıldı. Hayvanlarda BTZ ile kardiyotoksisite meydana getirebilmek için Xie ve ark.'nın [16] belirlediği kümülatif doz $\left(0,8 \mathrm{mg} \mathrm{kg}^{-1}\right)$ kullanıldı. BBR ise Moghaddam ve ark. [17] tarafindan belirlenen dozlara göre verildi. Gruplar şu şekilde dizayn edildi:

Sağlıklı Kontrol : Ratlara 1., 3., 5. ve 7. günlerde periton içi serum fizyolojik verildi.

Beberin-100 : Ratlara 10 gün boyunca her gün gastrik gavaj vasıtasıyla oral olarak $100 \mathrm{mg} \mathrm{kg}^{-1}$ vücut ağırlığı BBR verildi.

Bortezomib : Ratlara 1., 3., 5. ve 7. günlerde periton içi $0,2 \mathrm{mg} \mathrm{kg}^{-1}$ vücut ağırlığı BTZ verildi.

BTZ + BBR-50 : Ratlara 1., 3., 5. ve 7. günlerde periton içi $0,2 \mathrm{mg} \mathrm{kg}^{-1}$ vücut ağırlığı BTZ verildi. Ayrıca 10 gün boyunca her gün gastrik gavaj vasıtasıyla oral olarak $50 \mathrm{mg} \mathrm{kg}^{-1}$ vücut ağırlığı BBR verildi. 
BTZ + BBR-100 : Ratlara 1., 3., 5. ve 7. günlerde periton içi $0,2 \mathrm{mg} \mathrm{kg}^{-1}$ vücut ağırlığı BTZ verildi. Ayrıca 10 gün boyunca her gün gastrik gavaj vasitasiyla oral olarak $100 \mathrm{mg} \mathrm{kg}^{-1}$ vücut ağırlığı BBR verildi.

Son BBR uygulamasından 24 saat sonra (11. gün) ratlar hafif sevofloran anestezisi altında dekapite edilerek kanları ve kalp dokuları alındı. Kan örnekleri biyokimyasal analizler için antikoagulantsız vakumlu tüplere aktarlarak, 3000 devirde $+4{ }^{\circ} \mathrm{C}^{\prime} \mathrm{de} 10 \mathrm{dk}$. santrifüj edildikten sonra serumları ayrıldı ve biyokimyasal analizler yapılıncaya kadar $-80{ }^{\circ} \mathrm{C}$ 'de saklandı. Kalp dokuları serum fizyolojik ile yıkandıktan sonra biyokimyasal analizler yapılıncaya kadar aynı şekilde $-80{ }^{\circ} \mathrm{C}$ 'de saklandı.

\subsection{Kalp Dokusunda Lipid Peroksidasyon Derecelerinin Belirlenmesi}

Kalp dokusu bir homojenizatör vasıtasıyla (Tissue Lyser II, Qiagen, Netherlands) siv1 nitrojen içerisinde toz haline getirildi ve tüm analizlerde toz haline getirilmiş dokular kullanıldı. Ardından yine bu cihaz vasitasıyla dokular $1,15 \%$ potasyum klorür ile $1: 10\left(\mathrm{w} \mathrm{v} \mathrm{v}^{-1}\right)$ oranında sulandirılarak homojenize edildi. Elde edilen homojenatlar 15 dakika boyunca 3500 rpm'de santrifüj edildi. Lipid peroksidasyon derecesinin tespiti için elde edilen homojenatlarda MDA seviyeleri ölçüldü. MDA analizleri Placer ve ark.'nın [18] metoduna göre yapıldı. Sonuçlar nmol g ${ }^{-1}$ doku olarak belirlendi.

\subsection{Kalp Dokusunda Enzimatik ve Enzimatik Olmayan Antioksidanların Seviyelerinin Belirlenmesi}

Enzimatik (SOD, KAT ve GPx) ve enzimatik olmayan (GSH) antioksidan seviyeleri kalp dokusundan elde edilen homojenatlarda ölçüldü. SOD ve KAT aktiviteleri için homojenatlar 3500 rpm'de 15 dakika santrifüj edilirken GPx aktivitesi ve GSH miktarının ölçümü için 10000 rpm'de 20 dakika santrifüj edildi. Tüm analizlerde homojenatların santrifüj işlemi $+4{ }^{\circ} \mathrm{C}$ 'de gerçekleştirildi. SOD aktivitesi için Sun ve ark.'nın [19] metodu kullanıldı. Aktivite seviyesi $\mathrm{U} \quad \mathrm{g}^{-1}$ protein olarak belirlendi. KAT aktivitesi için Aebi'nin [20] belirlediği metot kullanıldı ve sonuçlar katal $\mathrm{g}^{-1}$ protein olarak verildi. GPx aktivitesi ve GSH miktarı sirasıyla Lawrence ve ark. [21] ve Sedlak ve ark'nın [22] metotlarına göre yapıldı. GPx aktivitesi seviyesi $\mathrm{U} \mathrm{g}^{-1}$ protein olarak verilirken GSH miktarı nmol g ${ }^{-1}$ olarak ifade edildi.

\subsection{Kalp Dokusunda Total Protein Seviyelerinin Analizi}

Kalp dokusunun total protein içeriği, Lowry ve ark.'nın [23] belirlediği yönteme göre daha önce elde edilen homojenatlar kullanılarak yapıldı.

\subsection{Kalp Dokusunda TAK ve TOK Seviyelerinin Belirlenmesi}

Kalp dokusunda total antioksidan kapasite (TAK) ve total oksidan kapasite (TOK) seviyeleri Erel'in sirasıyla
2004 [24] ve 2005 'de [25] geliștirdiği metotlara göre ticari kitler vasıtasıyla ELISA okuyucuda (Bio-Tek, Winooski, VT, ABD) ölçüldü.

\subsection{Kalp Dokusunda OSI'nin Belirlenmesi}

Oksidatif stres indeksi (OSI), TOK'un TAK'a oranıdır ve oksidatif stres derecesinin bir göstergesi olarak kabul edilmektedir [26].

\subsection{Kalp Dokusunda NO Seviyelerinin Belirlenmesi}

Kalp dokusunda total NO seviyesini ölçmek için ticari bir NO tespit kiti (Enzo Life Science, Katolog Numaras1: ADI-917-020) kullanıldı. Doku NO ölçümü, nitratın nitrite enzimatik dönüşümü ve Griess reaksiyonunun renkli bir azo boya ürünü olan nitritin kolorimetrik tespitine dayanır.

\subsection{Serum LDH Aktivitelerinin Belirlenmesi}

Serumdaki LDH aktivitesi Mindray Perfect Plus 400 cihazı kullanılarak test edildi. Sonuçlar $\mathrm{U} \mathrm{L}^{-1}$ olarak ifade edildi.

\subsection{1. İstatistiksel Analiz}

Biyokimyasal yöntemlerle elde edilen verilerin istatistiksel olarak incelenmesi, tek yönlü varyans analizi (One-way ANOVA) ile yapıldı. Gruplar arasında farkın olup olmadığı Tukey's multiple comparison testi ile belirlendi. Sonuçlar ortalama \pm standart hata (S.E.M) olarak verildi. $\mathrm{P}<0.05$ değeri istatistiksel olarak anlamlı kabul edildi.

\section{BULGULAR}

\subsection{Berberinin Kalp Dokusunda Lipid Peroksidasyon Seviyeleri Üzerine Etkisi}

Kalp dokusunda BTZ'nin neden olduğu lipid peroksidasyonuna karşı BBR'nin etkileri Şekil 1'de sunulmuştur. Elde edilen sonuçlar, BTZ'nin lipid peroksidasyonunun önemli bir göstergesi olan MDA seviyelerini kontrol grubuna göre arttırdığı belirlendi ( $p$ $<$ 0.05). Bununla birlikte BTZ kaynaklı lipid peroksidasyonunun BBR ile hafifleyerek kontrol grubu seviyelerine yaklaştığı görüldü $(\mathrm{p}<0.05)$. Ancak BBR'nin farklı dozları arasında istatistiksel olarak anlamlı bir farkın olmadığ tespit edildi.

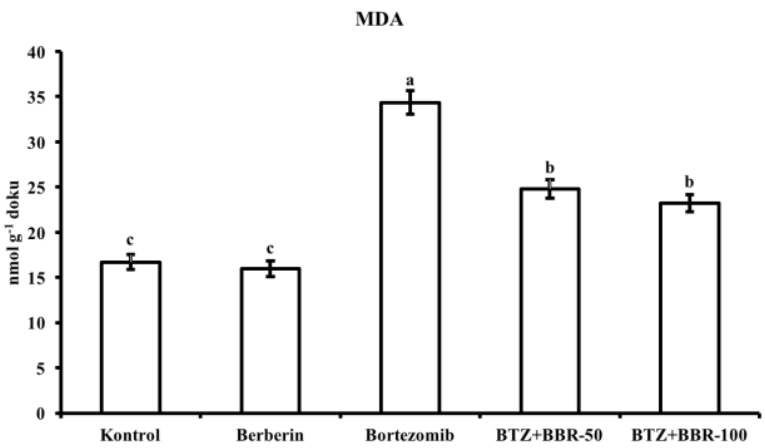

Sekil 1. Bortezomib ve berberin uygulamasının ratların kalp dokularında lipid peroksidasyon belirteci olan MDA seviyeleri üzerine etkileri. Veriler ortalama \pm S.E.M olarak ifade edildi. Sütunlar üzerindeki harfler $(\mathrm{a}-\mathrm{c})$ gruplar arası fark1 göstermektedir $(\mathrm{p}<0.05)$. (BTZ: Bortezomib, BBR: Berberin, MDA: Malondialdehit) 
3.2. Berberinin Kalp Dokusunda Enzimatik ve Enzimatik Olmayan Antioksidan Belirteçleri Üzerine Etkisi

Çalışmada, BTZ'nin antioksidan enzim aktivitelerini kontrol grubu ile karşılaştırıldığında inhibe ettiği belirlendi $(\mathrm{p}<0.05)$. Ayrıca vücuttaki önemli bir antioksidan olan GSH depolarının BTZ uygulaması ile azaldığı görüldü $(\mathrm{p}<0.05)$. Bu durum BTZ'nin kalp

A

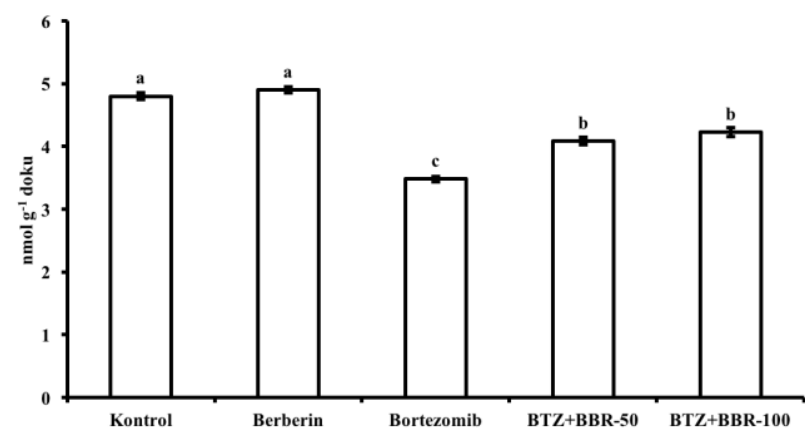

KAT

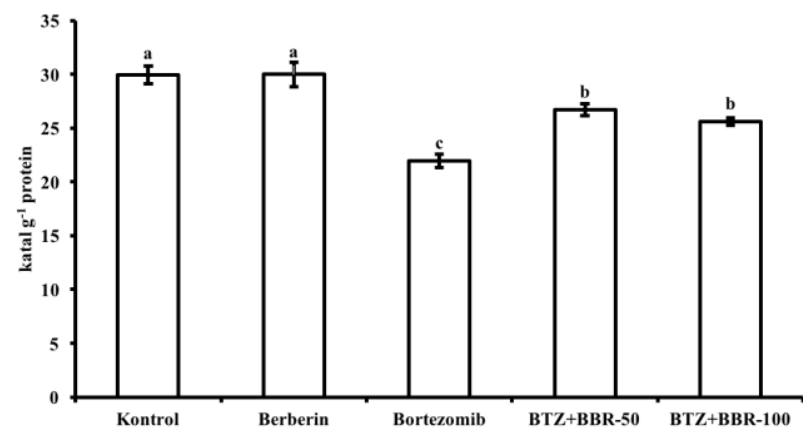

dokusunda oksidatif stres meydana getirdiğini göstermektedir. Buna karşın BTZ ile birlikte BBR uygulaması yapılan gruplarda yalnız BTZ grubuna göre GSH seviyelerinin arttığı ve SOD, KAT ve GPx aktivitelerinin kontrol grubu seviyelerine yaklaştığı belirlendi $(\mathrm{p}<0.05)$. Kalp dokusunda enzimatik ve enzimatik olmayan belirteçlere ait tüm sonuçlar Şekil 2'de özetlenmiş̧ir.
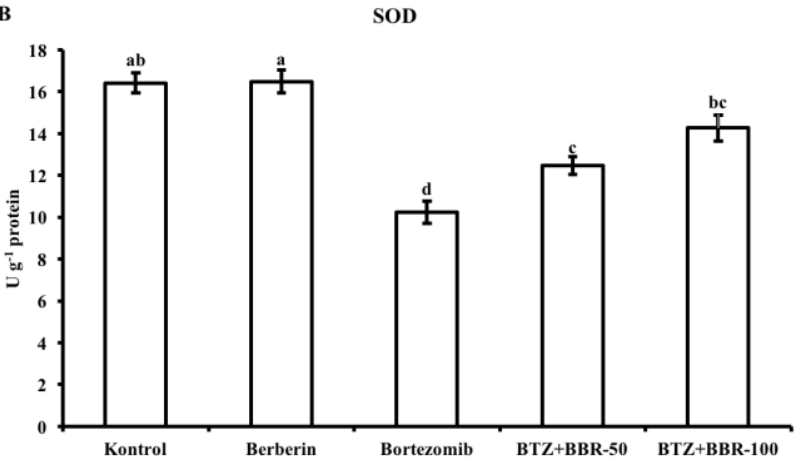

D

GPx

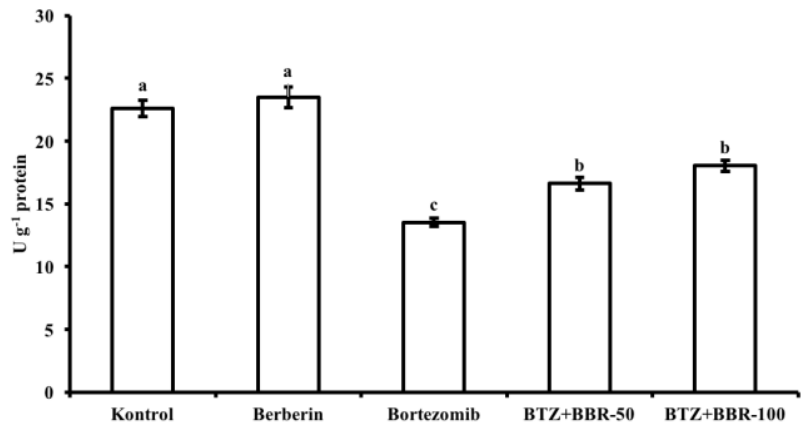

Sekil 2. Bortezomib ve berberin uygulamasının ratların kalp dokularında enzimatik (SOD, KAT ve GPx) ve enzimatik olmayan (GSH) antioksidan belirteçler üzerine etkileri. Veriler ortalama \pm S.E.M olarak ifade edildi. Sütunlar üzerindeki harfler (a-d) gruplar arası fark1 göstermektedir ( $\mathrm{p}<0.05$ ). (BTZ: Bortezomib, BBR: Berberin, GSH: Glutatyon, SOD: Süperoksit Dismutaz, KAT: Katalaz, GPx: Glutatyon Peroksidaz)

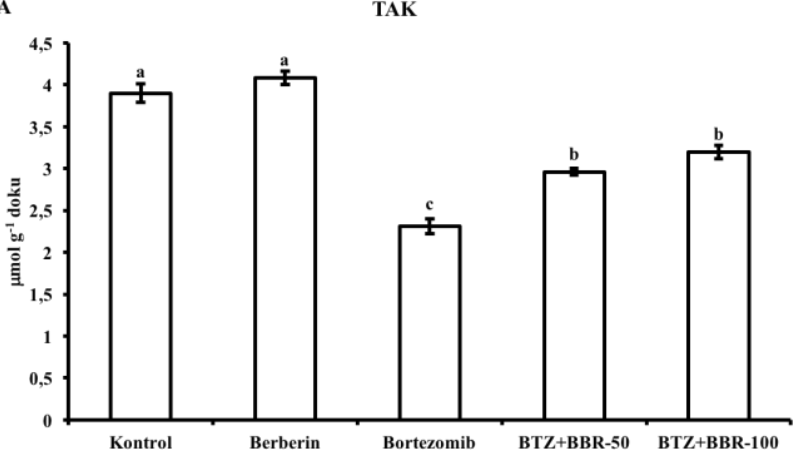

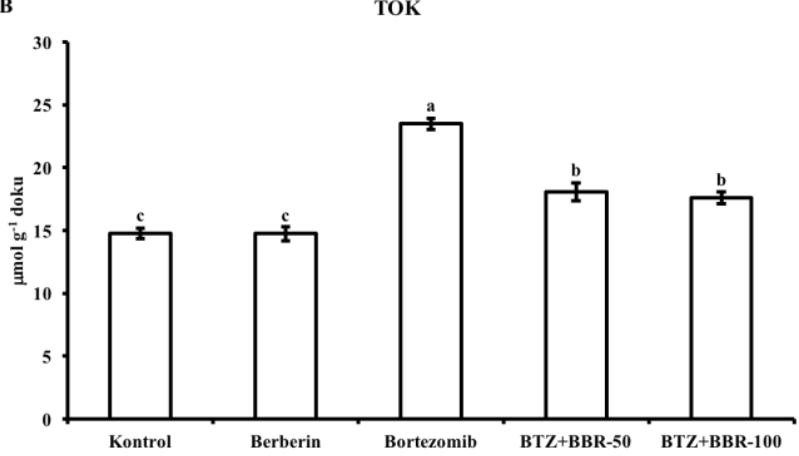

C

OSI

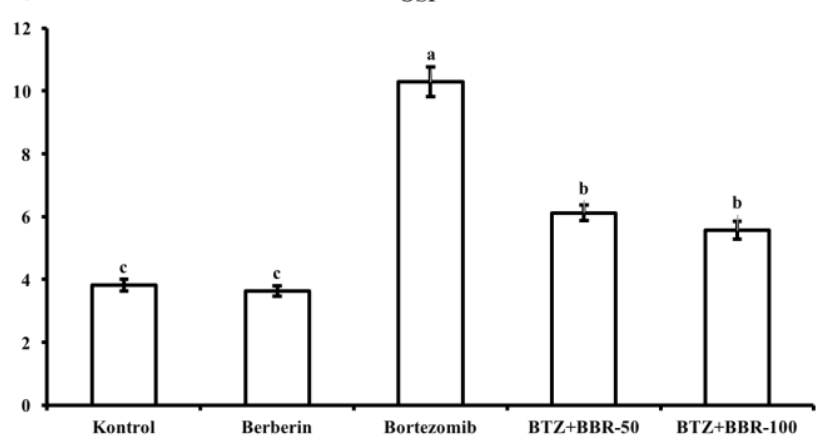

Şekil 3. Bortezomib ve berberin uygulamasının ratların kalp dokularında TAK, TOK ve OSI üzerine etkileri. Veriler ortalama \pm S.E.M olarak ifade edildi. Sütunlar üzerindeki harfler (a-c) gruplar arası fark1 göstermektedir ( $\mathrm{p}<0.05)$. (BTZ: Bortezomib, BBR: Berberin, TAK: Total Antioksidan Kapasite, TOK: Total Oksidan Kapasite, OSI: Oksidatif Stres İndeksi) 


\subsection{Berberinin Kalp Dokusunda TAK-TOK Seviyeleri ve OSI Üzerine Etkisi}

Sunulan çalışmada, BTZ'nin TOK seviyelerini ve OSI'yi kontrol grubuna göre arttırdığı, BBR'nin ise antioksidan özellik göstererek bu belirteçleri azalttığı tespit edildi ( $\mathrm{p}$ $<0.05$ ). Ayrıca BTZ'nin kalp dokusunda antioksidan kapasiteyi düşürdüğü görüldü $(\mathrm{p}<0.05)$. Buna karşın BTZ'nin azalttığ 1 TAK seviyelerini BBR'nin arttırarak kontrol grubu seviyelerine yaklaştırdığı belirlendi $(\mathrm{p}<$ 0.05). BBR'nin farklı dozları arasında ise istatistiksel olarak önemli bir fark görülmedi. Kalp dokusunda TAKTOK seviyeleri ile OSI'ye ait tüm sonuçlar Şekil 3'te sunulmuştur.

\subsection{Berberinin Kalp Dokusunda NO Seviyeleri Üzerine Etkisi}

Kalp dokusunda NO seviyeleri Şekil 4'te verilmiştir. Buna göre BTZ uygulaması yapılan hayvanların kalp dokularında NO seviyelerinin kontrol grubuna göre oldukça yüksek olduğu belirlendi $(\mathrm{p}<0.05)$. BTZ ile birlikte BBR verilen grupların NO seviyelerini yalnız BTZ uygulanan gruba göre doz bağımlı olarak azalttığı görüldü $(\mathrm{p}<0.05)$.

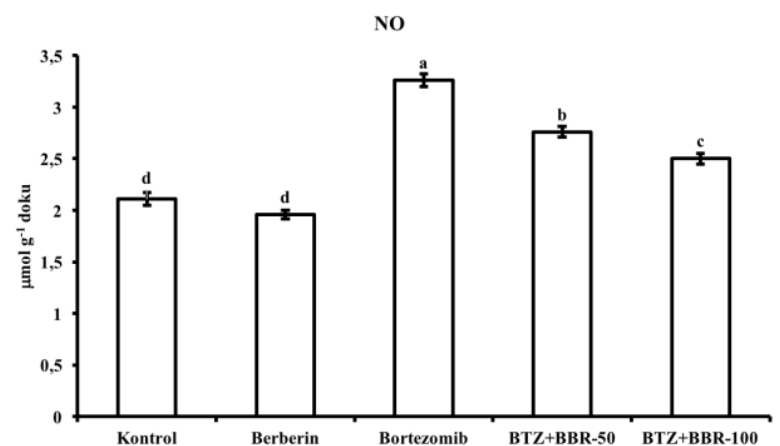

Şekil 4. Bortezomib ve berberin uygulamasının ratların kalp dokularında NO seviyeleri üzerine etkileri. Veriler ortalama \pm S.E.M olarak ifade edildi. Sütunlar üzerindeki harfler (a-d) gruplar arası farkı göstermektedir $(\mathrm{p}<0.05)$. (BTZ: Bortezomib, BBR: Berberin, NO: Nitrik Oksit)

\subsection{Berberinin Kalp Dokusunda LDH Aktiviteleri Üzerine Etkisi}

Çalışmada kalp hasarının önemli bir göstergesi olan LDH aktiviteleri ölçüldü ve elde edilen sonuçlar Şekil 5 'te özetlendi. Bulgulara göre BTZ'nin kontrol grubu ile karşılaş̧ırıldığında kalp dokusuna hasar vererek serum LDH aktivitelerinde artışa neden olduğu belirlendi $(\mathrm{p}<$

0.05). BBR ise BTZ kaynaklı kardiyak hasarı azaltarak LDH aktivitelerinin kontrol grubuna yaklasmasını sağladı $(\mathrm{p}<0.05)$. BBR'nin 50 ve $100 \mathrm{mg} \mathrm{kg}^{-1}$ vücut ağırlığı dozları arasında da istatistiksel olarak anlamlı bir farkın olduğu görüldü.

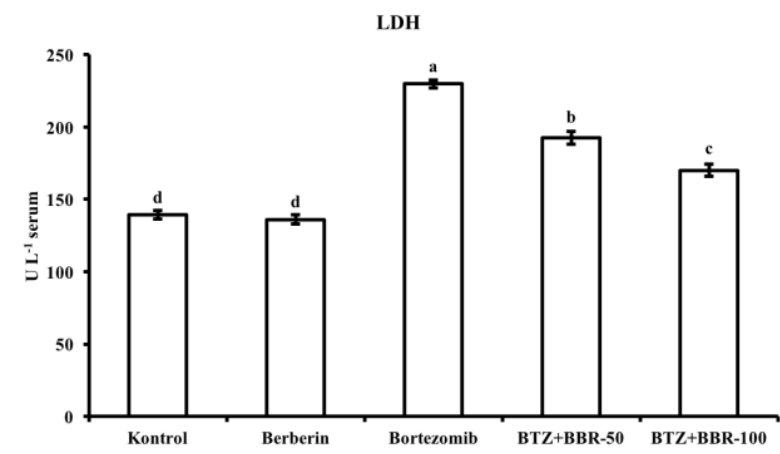

Sekil 5. Bortezomib ve berberin uygulamasının ratların kalp dokularında LDH aktiviteleri üzerine etkileri. Veriler ortalama \pm S.E.M olarak ifade edildi. Sütünlar üzerindeki harfler (a-d) gruplar arası fark göstermektedir $(\mathrm{p}<0.05)$. (BTZ: Bortezomib, BBR: Berberin, LDH: Laktat Dehidrogenaz)

\section{TARTISMA}

Tümör hücrelerinde hayati hücresel yolları hedefleyen yeni ilaçların kullanımı, neoplastik hastalıklar için tedavi sonuçlarını önemli ölçüde iyileştirmiştir [27, 28]. Bcr$\mathrm{Abl}$ antagonistleri, monoklonal antikorlar ve proteazom inhibitörleri gibi ilaçlarla hematolojik malignitelerin tedavilerinde iyi sonuçlar elde edilmiştir. Bu başarıların sonucu olarak uzun vadeli hayatta kalan hasta sayısinda önemli derecede artışlar meydana gelmektedir. Bununla birlikte kanser tedavilerinin komplikasyonları da dahil olmak üzere buna eşlik eden hastalıkların önemi de her geçen gün artmaktadır [7]. BTZ ile ilgili literatürde dikkat çekici bir oranda nörotoksisite çalışmaları bulunmakta fakat kardiyotoksik etkileri ve bu etkileri iyileştirebilecek maddeler yeteri kadar araştırılmamıştır. Bundan yola çıkılarak sunulan çalışmada BTZ'nin neden olduğu kardiyotoksisiteye karșı BBR'nin etkileri bazı biyokimyasal belirteçler kullanılarak araştırılmıştır. Elde edilen bulgular, BTZ'nin özellikle oksidatif strese yol açarak kardiyotoksisiteye neden olduğu ve bu toksik etkilere karşı BBR'nin umut verici bir madde olduğu ortaya çıkmıştır.

ROS'lar ve RNS'ler, oksidatif fosforilasyon sırasinda fizyolojik olarak oluşan serbest radikallerdir. Çeşitli fizyolojik rolleri vardır ve vücuttan hızla uzaklaştırılırlar [29]. Oksidatif stres, ROS'ların seviyelerinde artış veya antioksidan seviyelerinde bir azalmanın sonucu olarak meydana gelir. Yani oksidan türlerin seviyesi antioksidan seviyelerini aştığında, redoks homeostazı bozulur [30] ve bu da oksidatif strese neden olur. Normal sinyal iletim süreçleri için düşük konsantrasyonlarda oksidan türlere ihtiyaç duyulsa da bu maddelerin daha yüksek seviyelerinin birçok patolojik durumda rol oynadığı gösterilmiştir [31-33] ROS'ların çoğu mitokondride üretilmektedir. Kardiyomiyositler mitokondri bakımından oldukça zengin hücrelerdir. Öyle ki kardiyomiyositlerdeki mitokondri sayısı diğer dokulara göre \% 35-40 daha fazladır. Bu durum kalp hücrelerinde ROS üretiminin daha fazla olmasina ve oksidatif stresin daha şiddetli gerçekleşmesine neden olmakta ve sonuç olarak doku hasarına karşı daha duyarlı olmasına neden olmaktadır [34].

Lipitler, serbest radikal hasarına en duyarlı substratlardır $[35,36]$. MDA, çoklu doymamış yağ asitlerinin 
oksidasyon ürünüdür ve artan MDA içeriği, lipid peroksidasyonunun önemli bir göstergesi olarak kabul edilmektedir [37-39]. Önceki çalışmalarda çeşitli toksik ajanların ROS üretimine bağlı olarak lipid peroksidayonu meydana getirdiğini ve buna bağlı olarak MDA seviyelerinde artışların olduğu bildirilmiștir [4044]. Artan MDA seviyelerinin oksidatif stresin önemli bir göstergesi olduğunu ve oksidatif stresin de kalp dahil çeşitli dokularda toksisiteye yol açtığı yapılan çalışmalarda kanıtlanmıştır [28, 45-47]. Sunulan çalışmada BTZ'nin kalp dokusunda lipit peroksidasyonuna neden olarak MDA seviyelerini önemli derecede arttırması, bu dokuda oksidatif stresi tetiklediğini göstermektedir. Bununla birlikte BBR'nin antioksidan özellik göstererek oksidatif stresi hafiflettiği ve kalp dokusunu BTZ kaynaklı hasardan koruyabileceğini gösterdi. Önceki bir çalışmada da BBR'nin methotrexate ile indüklenen toksisitede oksidatif strese karşı koruyucu özellik göstererek MDA seviyelerini azalttığı rapor edilmiştir [15].

Biyolojik sistemlerdeki serbest radikallerin ortadan kaldırılması, serbest radikallere karşı önemli savunma sistemleri olarak işlev gören enzimatik ve enzimatik olmayan antioksidanlar tarafindan sağlanır [48-52]. İndirgenmiş GSH, ROS'ları (peroksinitrit, hidroksil radikali, lipid peroksil radikali ve $\mathrm{H}_{2} \mathrm{O}_{2}$ ) ve diğer serbest radikalleri temizleyen enzimatik olmayan bir antioksidandır. GSH, GPx için bir substrat görevi görür. $\mathrm{Bu}$ nedenle GSH seviyelerindeki düşüş, azalmış GPx aktivitesi ile sonuçlanır. Diğer antioksidan enzimler, sırasıyla süperoksit anyonlarının ve hidrojen peroksitin parçalanmasını katalize eden SOD ve KAT'dır [53]. Miyokardın diğer dokulara göre SOD, KAT ve GPx gibi antioksidan enzim içeriğini daha düşük seviyelerde bulundurmas1, oksidatif stresin daha şiddetli gerçekleşmesine neden olmaktadır. SOD, zararlı süperoksit radikallerini $\mathrm{H}_{2} \mathrm{O}_{2}$ 'ye dönüştürebilen doğal bir süperoksit radikal temizleyicisidir [34]. KAT enzimi $\mathrm{H}_{2} \mathrm{O}_{2}$ 'yi moleküler oksijen ve suya parçalayarak oksidatif stresin azalmasina katkıda bulunabilir [48]. GPx enzimi hem mitokondri hem de sitozolde bulunur ve $\mathrm{H}_{2} \mathrm{O}_{2}$ 'nin temizlenmesinde merkezi bir role sahiptir [34]. $\mathrm{Bu}$ enzimler, ROS'ları gidermek için birlikte çalışırlar ve fizyolojik konsantrasyonlarındaki küçük sapmalar, hücresel proteinlerin, lipitlerin ve DNA'nın oksidatif hasara karşı direnci üzerinde etkili olabilir. Sonuç olarak bu antioksidan enzimlerin aktivitesi, dokuları ve organları oksidatif strese karşı korumak için gerekli olan önemli faktörlerdir [48]. Önceki çalışmalarda çeşitli kanser türlerinin tedavilerinde kullanılan ilaçların vücutta antioksidan savunma sisteminde görevli olan bu enzimatik ve enzimatik olmayan antioksidanların aktivitelerini ve seviyelerini azaltarak oksidatif strese neden olduğu ve dokularda işlev bozukluğuna yol açan toksisiteleri meydana getirdikleri rapor edilmiştir [54-59]. Sunulan çalışmada BTZ'nin kalp dokusunda SOD, KAT ve GPx aktiviteleri ile GSH seviyelerini azalttığı ve sonuç olarak oksidatif stres oluşumuna önemli bir katkı sağladığı belirlendi. Bununla birlikte BBR'nin bu antioksidanların seviyelerini arttırarak oksidatif stresi hafiflettiği görüldü. Önceki çalışmalarda benzer şekilde BBR'nin kanser tedavisinde kullanılan farklı ilaçlarla meydana getirilen oksidatif stresi azaltarak dokularda önemli bir koruma sağladığı bildirilmiştir $[15,60]$.

Serum ve dokularda çok sayıda farklı antioksidan bileşen vardır. Antioksidan durumunun belirlenmesi için her bir antioksidan bileşenin ölçülmesi zordur. Ayrıca bazı antioksidanların birbirine yardımcı etki göstermelerinden dolayı sadece bir antioksidanın belirlenmesi, kombine etkilerini doğru şekilde yansıtamaz [61]. Aynı şekilde oksidan moleküllerin tek tek ölçümü pratik olmadığından, oksidatif stresi değerlendirmek için farklı bir parametre olarak TOK seviyesinden yararlanılabilir [24]. Son derece yüksek ROS üretiminde, vücudun yapısal ve fonksiyonel bütünlüğünü korumak için antioksidan enzimler de arttırılır. Bu nedenle, vücuttaki oksidatif stresin tam olarak belirlenmesi için TAK ve TOK seviyelerinin test edilmesi yetersiz olabilir [35]. OSI, oksidatif stresin belirlenmesi için anahtar faktördür. $\mathrm{Bu}$ konu ile ilgili sunulan bir çalışmada, kanser tedavisinde etkin olarak kullanılan cisplatinin TAK seviyelerini değiștirmediği, TOK seviyeleri ve OSI'de ise artışa neden olduğu belirtilmiştir [26]. Sunulan çalışmada ise BTZ'nin TAK seviyelerini önemli ölçüde azalttığı, TOK seviyelerini ve OSI'yi ise arttırdığ 1 belirlendi. Buna karşın BBR'nin OSI'yi ve TOK seviyelerini azaltarak, TAK seviyelerini ise arttırarak oksidatif strese karş1 önemli bir koruyucu etki gösterdi. Bizim sonuçlarımıza benzer olarak önceki bir çalışmada BBR'nin kurşun ile indüklenen oksidatif strese karş1 koruyucu özellik gösterdiği ve kurşunun arttırdığı TOK seviyelerini azalttığı ve azalmış TAK seviyelerini ise kontrol grubu seviyelerine çektiği bildirilmiştir [62].

Vasküler tonusun önemli bir belirleyicisi olduğu bilinen ve kalp fonksiyonu ve hastalıkta farklı rollere sahip olabilen bir diatomik serbest radikal olan NO'nun, birçok kardiyovasküler hastalık formunun patofizyolojisinde önemli bir rol oynadığı bulunmuştur. Yakın zamanda aşırı NO'nun miyokardiyal kontraktiliteyi azaltarak ve ejeksiyon süresini kısaltarak sistolik fonksiyonu baskıladığ gösterilmiştir [63]. Birkaç antineoplazik ajanın NO üretimini uyardığ gösterilmiştir $[64,65]$. Sunulan çalışmada BTZ'nin de NO seviyelerini arttırdığ 1 ve buna bağlı olarak nitrozatif stres meydana getirdiği belirlendi. Öte yandan BBR uygulamasının NO seviyelerini azaltarak nitrozatif stresi hafiflettiği görüldü.

Calıșmamızda BTZ kaynaklı oksidatif stresin kalp dokusunda meydana getirdiği hasar hakkında fikir edinebilmek için serumda LDH aktivitesi ölçüldü. Sonuçlar BTZ'nin serum LDH aktivitesinde artışa neden olduğunu gösterdi. Buna karşın BTZ ile artan serum LDH aktivitesinin BBR uygulaması ile azaldığ belirlendi. Önceki bir çalışmada cisplatinin kardiyak hasar meydana getirerek LDH seviyelerinde artış meydana getirdiği bildirilmiştir [66]. Başka bir çalışmada doksorubisin uygulamasının miyokardiyal hasara neden olarak arttırdığ $\mathrm{LDH}$ aktivitesini BBR'nin normal seviyelere indirdiği ve bu fitokimyasalın doksorubisine bağlı kardiyotoksisitede koruyucu bir role sahip olabileceği belirtilmiştir [67] 


\section{SONUÇ}

Birlikte ele alındığında, BTZ'nin oksidatif strese bağlı olarak kalp dokusunda toksisite meydana getirebileceği ve meydana gelen bu toksisiteye karşı BBR'nin önemli bir koruyucu etkinliğe sahip olabileceği belirlendi. BTZ kaynaklı kardiyak toksisitede BBR'nin etkilerinin daha ileri çalışmalar ile araştırılmasından sonra bu bitkisel ilacın BTZ hasarına karşı koruyucu olarak kullanılabileceği düşünülmektedir.

\section{KAYNAKLAR}

[1] Argyriou AA, Cavaletti G, Bruna J, Kyritsis AP, Kalofonos HP. Bortezomib-induced peripheral neurotoxicity: an update. Arch Toxicol. 2014;88(9):1669-1679.

[2] Shen M, Schmitt S, Buac D, Dou QP. Targeting the ubiquitin-proteasome system for cancer therapy. Expert Opin Ther Targets. 2013;17(9):1091-1108.

[3] Meregalli C, Canta A, Carozzi VA, Chiorazzi A, Oggioni N, Gilardini A, et al. Bortezomib-induced painful neuropathy in rats: a behavioral, neurophysiological and pathological study in rats. Eur J Pain. 2010;14(4):343-350.

[4] Jerkins JH, Suciu A, Mazimba S, Calvo A. Bortezomib-induced severe congestive heart failure. Cardiol Res. 2010;1(1):20.

[5] Reece DE, Sullivan D, Lonial S, Mohrbacher AF, Chatta G, Shustik C, et al. Pharmacokinetic and pharmacodynamic study of two doses of bortezomib in patients with relapsed multiple myeloma. Cancer Chemother Pharmacol. 2011;67(1):57-67.

[6] Hasinoff BB, Patel D, Wu X. Molecular mechanisms of the cardiotoxicity of the proteasomal-targeted drugs bortezomib and carfilzomib. Cardiovasc Toxicol. 2017;17(3):237250.

[7] Nowis D, Mączewski M, Mackiewicz U, Kujawa M, Ratajska A, Wieckowski MR, et al. Cardiotoxicity of the anticancer therapeutic agent bortezomib. Am J Pathol. 2010;176(6):2658-2668.

[8] Voortman J, Giaccone G. Severe reversible cardiac failure after bortezomib treatment combined with chemotherapy in a non-small cell lung cancer patient: a case report. BMC cancer. 2006;6(1):1-4.

[9] Orciuolo E, Buda G, Cecconi N, Galimberti S, Versari D, Cervetti G, et al. Unexpected cardiotoxicity in haematological bortezomib treated patients. Br J Haematol. 2007;138(3):396-397.

[10] Ojha S, Al Taee H, Goyal S, Mahajan UB, Patil CR, Arya D, et al. Cardioprotective potentials of plant-derived small molecules against doxorubicin associated cardiotoxicity. Oxid Med Cell Longev. 2016;2016.

[11] Kok L, Wong Y, Wu T, Chan H, Kwok T, Fung K. Morin hydrate: a potential antioxidant in minimizing the free-radicals-mediated damage to cardiovascular cells by anti-tumor drugs. Life sci. 2000;67(1):91-99.

[12] Abushouk AI, Ismail A, Salem AMA, Afifi AM, Abdel-Daim MM. Cardioprotective mechanisms of phytochemicals against doxorubicin-induced cardiotoxicity. Biomed Pharmacother. 2017;90:935-946.

[13] Lau CW, Yao XQ, Chen ZY, Ko WH, Huang Y. Cardiovascular actions of berberine. Cardiovasc Drug Rev. 2001;19(3):234-244.

[14] Javad-Mousavi SA, Hemmati AA, Mehrzadi S, Hosseinzadeh A, Houshmand G, Nooshabadi MRR, et al. Protective effect of Berberis vulgaris fruit extract against Paraquat-induced pulmonary fibrosis in rats. Biomed Pharmacother. 2016;81:329-336.

[15] Mehrzadi S, Fatemi I, Esmaeilizadeh M, Ghaznavi H, Kalantar H, Goudarzi M. Hepatoprotective effect of berberine against methotrexate induced liver toxicity in rats. Biomed Pharmacother. 2018;97:233-239.

[16] Xie J-D, Chen S-R, Chen H, Pan H-L. Bortezomib induces neuropathic pain through protein kinase Cmediated activation of presynaptic NMDA receptors in the spinal cord. Neuropharmacology. 2017;123:477-487.

[17] Moghaddam HK, Baluchnejadmojarad T, Roghani M, Khaksari M, Norouzi P, Ahooie M, et al. Berberine ameliorate oxidative stress and astrogliosis in the hippocampus of STZ-induced diabetic rats. Mol Neurobiol. 2014;49(2):820-826.

[18] Placer ZA, Cushman LL, Johnson BC. Estimation of product of lipid peroxidation (malonyl dialdehyde) in biochemical systems. Anal Biochem. 1966;16(2):359-364.

[19] Sun Y, Oberley LW, Li Y. A simple method for clinical assay of superoxide dismutase. Clin Chem. 1988;34(3):497-500.

[20] Aebi H. [13] Catalase in vitro. Methods in enzymology. 105: Elsevier; 1984. p. 121-126.

[21] Lawrence RA, Burk RF. Glutathione peroxidase activity in selenium-deficient rat liver. Biochem Biophys Res Commun. 1976;71(4):952-958.

[22] Sedlak J, Lindsay RH. Estimation of total, proteinbound, and nonprotein sulfhydryl groups in tissue with Ellman's reagent. Anal Biochem. 1968;25:192-205.

[23] Lowry OH, Rosebrough NJ, Farr AL, Randall RJ. Protein measurement with the Folin phenol reagent. J Biol Chem. 1951;193:265-275.

[24] Erel O. A novel automated direct measurement method for total antioxidant capacity using a new generation, more stable ABTS radical cation. Clin Biochem. 2004;37(4):277-285.

[25] Erel O. A new automated colorimetric method for measuring total oxidant status. Clin Biochem. 2005;38(12):1103-1111.

[26] Cagin YF, Erdogan MA, Sahin N, Parlakpinar H, Atayan Y, Polat A, et al. Protective effects of apocynin on cisplatin-induced hepatotoxicity in rats. Arch Med Res. 2015;46(7):517-526.

[27] Caglayan C, Temel Y, Kandemir FM, Yildirim S, Kucukler S. Naringin protects against cyclophosphamide-induced hepatotoxicity and nephrotoxicity through modulation of oxidative stress, inflammation, apoptosis, autophagy, and 
DNA damage. Environ. Sci. Pollut. Res. 2018;25(21):20968-20984.

[28] Aybek H, Temel Y, Ahmed BM, Ağca CA, Çiftci $M$. Deciphering of the effect of chemotherapeutic agents on human glutathione s-transferase enzyme and MCF-7 cell line. Protein Pept. Lett. 2020;27(9):888-894.

[29] Hanedan B, Kirbas A, Kandemir FM, Ozkaraca M, Kilic K, Benzer F. Arginase activity and total oxidant/antioxidant capacity in cows with lung cystic echinococcosis. Med Weter. 2015;71(3):167170.

[30] Aksu EH, Kandemir FM, Küçükler S. Naringin'in erkek ratlarda methotreaxte indüklü testis apoptosisi ve otofajisi üzerine oksidatif stresi azaltmak yoluyla koruyucu etkisi. FÜ Sağ Bil Derg. 2018;32(3):179-183.

[31] Özdemir S, Kucukler S, Çomaklı S, Kandemir FM. The protective effect of Morin against ifosfamideinduced acute liver injury in rats associated with the inhibition of DNA damage and apoptosis. Drug Chem Toxicol. 2020:1-10.

[32] Kucukler S, Caglayan C, Darendelioğlu E, Kandemir FM. Morin attenuates acrylamideinduced testicular toxicity in rats by regulating the NF- $\kappa$ B, Bax/Bcl-2 and PI3K/Akt/mTOR signaling pathways. Life Sci. 2020;261:118301.

[33] Sangomla S, Saifi MA, Khurana A, Godugu C. Nanoceria ameliorates doxorubicin induced cardiotoxicity: possible mitigation via reduction of oxidative stress and inflammation. J Trace Elem Med Biol. 2018;47:53-62.

[34] Songbo M, Lang H, Xinyong C, Bin X, Ping Z, Liang S. Oxidative stress injury in doxorubicininduced cardiotoxicity. Toxicol Lett. 2019;307:4148.

[35] Aktas MS, Kandemir FM, Kirbas A, Hanedan B, Aydin MA. Evaluation of oxidative stress in sheep infected with Psoroptes ovis using total antioxidant capacity, total oxidant status, and malondialdehyde level. J Vet Res. 2017;61(2):197-201.

[36] Erişir M, Kandemir FM, Benzer F. Koç katımının kandaki malondialdehit ve bazı antioksidanlar üzerine etkileri. Atatürk Üniversitesi Vet Bil Derg.5(2):49-54.

[37] Yardim A, Kandemir FM, Ozdemir S, Kucukler S, Comakli S, Gur C, et al. Quercetin provides protection against the peripheral nerve damage caused by vincristine in rats by suppressing caspase 3 , NF- $\kappa$ B, ATF-6 pathways and activating Nrf2, Akt pathways. NeuroToxicology. 2020.

[38] Kandemir FM, Erişir M, Yüksel M. Comparison of lipid peroxidation and several antioxidants in blood of normally calved and dystocia affected cows and their newborn calves. Isr J Vet Med. 2016;71(2):19-23.

[39] Kandemir FM, Küçükler S, Çağlayan C. Beneficial effects of silymarin and naringin against methotrexate-induced hepatotoxicity in rats. Atatürk Üniversitesi Vet Bil Derg. 2017;12(2):167177.

[40] Kaymaz MB, Kandemir FM, Pamukcu E, Eröksüz Y, Özdemir N. Effects of aqueous artichoke
(Cynara scolymus) leaf extract on hepatic damage generated by alpha-amanitine. Kafkas Univ Vet Fak Derg. 2017;23(1):155-160.

[41] Aktaş MS, Kandemir FM, Özkaraca M, Hanedan B, Kırbaş A. Protective effects of rutin on acute lung injury induced by oleic acid in rats. Kafkas Univ Vet Fak Derg. 2017;23(3):443-451.

[42] Kandemir FM, Caglayan C, Aksu EH, Yildirim S, Kucukler S, Gur C, et al. Protective effect of rutin on mercuric chloride-induced reproductive damage in male rats. Andrologia. 2020;52(3):e13524.

[43] Yardım A, Kucukler S, Özdemir S, Çomaklı S, Caglayan C, Kandemir FM, et al. Silymarin alleviates docetaxel-induced central and peripheral neurotoxicity by reducing oxidative stress, inflammation and apoptosis in rats. Gene. 2020:145239.

[44] Yardım A, Kandemir FM, Çomaklı S, Özdemir S, Caglayan C, Kucukler S, et al. Protective effects of curcumin against paclitaxel-induced spinal cord and sciatic nerve injuries in rats. Neurochem. Res. 2020:1-17.

[45] Aksu EH, Kandemir FM, Küçükler S, Mahamadu A. Improvement in colistin-induced reproductive damage, apoptosis, and autophagy in testes via reducing oxidative stress by chrysin. J Biochem Mol Toxicol. 2018;32(11):e22201.

[46] Küçükler S, Özdemir S, Çomakli S, Kandemir FM. Ratlarda izoniazid kaynaklı akciğer hasarına karşı krisinin etkileri. Kocatepe Vet Derg.13(2):161-171.

[47] Küçükler S, Özdemir S, Kandemir FM, Çağlayan C. Ratlarda kadmiyum kaynaklı mide toksisitesine karşı karvakrol'un etkileri. Tr Doğa Fen Derg. 9(1):12-18.

[48] Kucukler S, Darendelioğlu E, Caglayan C, Ayna A, Yıldırım S, Kandemir, FM. Zingerone attenuates vancomycin-induced hepatotoxicity in rats through regulation of oxidative stress, inflammation and apoptosis. Life Sci. 2020;259: 118382.

[49] Temel Y, Koçyigit UM, Taysı MŞ, Gökalp F, Gürdere MB, Budak Y, et al. Purification of glutathione $\mathrm{S}$-transferase enzyme from quail liver tissue and inhibition effects of ( $3 \mathrm{aR}, 4 \mathrm{~S}, 7 \mathrm{R}, 7 \mathrm{aS})$ 2-(4-((E)-3-(aryl) acryloyl) phenyl)-3a, 4, 7, 7atetrahydro-1H-4, 7-methanoisoindole-1, 3 (2H)dione derivatives on the enzyme activity. J Biochem Mol Toxicol. 2018;32(3):e22034.

[50] Temel Y, Çağlayan C, Ahmed BM, Kandemir FM, Çiftci M. The effects of chrysin and naringin on cyclophosphamide-induced erythrocyte damage in rats: biochemical evaluation of some enzyme activities in vivo and in vitro. NaunynSchmiedeberg's Arch. Pharmacol. 2020:1-10.

[51] Temel Y, Küfrevioğlu Öİ, Ciftci M. Investigation of the effects of purification and characterization of turkey (Meleagris gallopavo) liver mitochondrial thioredoxin reductase enzyme and some metal ions on enzyme activity. Turk. J. Chem. 2017;41(1):4860.

[52] Temel Y, Taysi MŞ. The effect of mercury chloride and boric acid on rat erythrocyte enzymes. Biol. Trace Elem. Res. 2019;191(1):177-182. 
[53] Abdel-Daim MM, Khalifa HA, Ahmed AA. Allicin ameliorates doxorubicin-induced cardiotoxicity in rats via suppression of oxidative stress, inflammation and apoptosis. Cancer Chemother Pharmacol. 2017;80(4):745-753.

[54] Kucukler S, Benzer F, Yildirim S, Gur C, Kandemir FM, Bengu AS, et al. Protective effects of chrysin against oxidative stress and inflammation induced by lead acetate in rat kidneys: a biochemical and histopathological approach. Biol Trace Elem Res. 2020:1-14.

[55] Celik H, Kucukler S, Comakli S, Ozdemir S, Caglayan C, Yardim A, et al. Morin attenuates ifosfamide-induced neurotoxicity in rats via suppression of oxidative stress, neuroinflammation and neuronal apoptosis. Neurotoxicology. 2020;76:126-137.

[56] Kandemir FM, Kucukler S, Caglayan C, Gur C, Batil AA, Gülçin İ. Therapeutic effects of silymarin and naringin on methotrexate-induced nephrotoxicity in rats: Biochemical evaluation of anti-inflammatory, antiapoptotic, and antiautophagic properties. J Food Biochem. 2017;41(5):e12398.

[57] Çelik H, Kucukler S, Çomaklı S, Caglayan C, Özdemir S, Yardım A, et al. Neuroprotective effect of chrysin on isoniazid-induced neurotoxicity via suppression of oxidative stress, inflammation and apoptosis in rats. Neurotoxicology. 2020;81:197208.

[58] Celik H, Kucukler S, Ozdemir S, Comakli S, Gur C, Kandemir FM, et al. Lycopene protects against central and peripheral neuropathy by inhibiting Oxaliplatin-induced ATF-6 pathway, apoptosis, inflammation and oxidative stress in brains and sciatic tissues of rats. NeuroToxicology. 2020.

[59] Çelik H, Kandemir FM, Caglayan C, Özdemir S, Çomaklı S, Kucukler S, et al. Neuroprotective effect of rutin against colistin-induced oxidative stress, inflammation and apoptosis in rat brain associated with the CREB/BDNF expressions. Mol. Biol. Rep. 2020;47(3):2023-2034.

[60] Xiong C, Wu YZ, Zhang Y, Wu ZX, Chen XY, Jiang $P$, et al. Protective effect of berberine on acute cardiomyopathy associated with doxorubicin treatment. Oncol Lett. 2018;15(4):5721-5729.

[61] Cao G, Prior RL. Comparison of different analytical methods for assessing total antioxidant capacity of human serum. Clin Chem. 1998;44(6):1309-1315.

[62] Hasanein P, Riahi H. Preventive use of berberine in inhibition of lead-induced renal injury in rats. Environ Sci Pollut Res. 2018;25(5):4896-4903.

[63] Mohan P, Brutsaert DL, Paulus WJ, Sys SU. Myocardial contractile response to nitric oxide and cGMP. Circulation. 1996;93(6):1223-1229.

[64] Son K, Kim Y-M. In vivo cisplatin-exposed macrophages increase immunostimulant-induced nitric oxide synthesis for tumor cell killing. Cancer res. 1995;55(23):5524-5527.

[65] Bani D, Masini E, Bello MG, Bigazzi M, Sacchi TB. Relaxin activates the L-arginine-nitric oxide pathway in human breast cancer cells. Cancer res. 1995;55(22):5272-5275.

[66] El-Awady E-SE, Moustafa YM, Abo-Elmatty DM, Radwan A. Cisplatin-induced cardiotoxicity: Mechanisms and cardioprotective strategies. Eur J Pharmacol. 2011;650(1):335-341.

[67] Zhao X, Zhang J, Tong N, Liao X, Wang E, Li Z, et al. Berberine attenuates doxorubicin-induced cardiotoxicity in mice. J Int Med Res. 2011;39(5):1720-1727. 